\title{
Kadmiyum Maruziyetine Bağlı Osteoporoz
}

\author{
Osteoporosis Due to Cadmium Exposure \\ Mustafa Turgut Yıldızgören, Timur Ekiz*, Ali Erdem Baki, Engin Tutkun** \\ Ankara Meslek Hastalıkları Hastanesi, Fizik Tedavi ve Rehabilitasyon Kliniği, Ankara, Türkiye \\ *Ankara Fizik Tedavi ve Rehabilitasyon Eğitim ve Araştırma Hastanesi, Fizik Tedavi ve Rehabilitasyon Kliniği, Ankara, Türkiye \\ ${ }^{* * A n k a r a ~ M e s l e k ~ H a s t a l ı k l a r ı ~ H a s t a n e s i, ~ T o k s i k o l o j i ~ K l i n i g ̆ i, ~ A n k a r a, ~ T u ̈ r k i y e ~}$
}

\section{Özet}

Bu makalede kronik kadmiyum maruziyetine bağlı osteoporoz gelişen 35 yaşında erkek hasta sunuldu. Bu vaka aracılığıyla kadmiyum ve osteoporoz arasındaki ilişki tartışıldı. Meslek hastalıklarının önlenmesinin önemi vurgulandı. (Türk Osteoporoz Dergisi 2014;20: 34-5)

Anahtar kelimeler: Kadmiyum, kemik mineral yoğunluğu, osteoporoz, meslek hastalığı

\section{Summary}

In this paper, presented is a 35 year-old man with osteoporosis due to chronic cadmium exposure. Association between osteoporosis and cadmium has been discussed via this case. Prevention of occupational diseases has been highlighted. (Turkish Journal of Osteoporosis 2014;20: 34-5)

Key words: Cadmium, bone mineral density, osteoporosis, occupational disaese

\section{Giriş}

Kadmiyum çevresel ve mesleki olarak önemli bir kontaminanttır Kadmiyum bileşikleri toz ve aerosol şeklinde bulunurlar ve inhale edilirler. Kronik inhalasyon sonucu toksik etkiler gelişebilir. Başta akciğer ve böbrek (renal tübüler disfonksiyon, renal taş ve hiperkalsiüri) olmak üzere vitamin $D$ seviyesi ve kemik mineralizasyonu üzerine olumsuz etkileri bildirilmiştir (1). Ancak, literatürde mesleki kadmiyum maruziyetine bağlı gelişen osteoporoz ile ilgili sınırlı sayıda makale vardır (2-4). $\mathrm{Bu}$ nedenle, burada mesleki kadmiyum maruziyeti sonrası osteoporoz görülen bir olgu sunuldu. Bu vaka aracılığıyla meslek hastalıklarının önemi vurgulandı.

\section{Olgu}

Otuz beş yaşında, 2 yıl havacılık sektöründe metal kaplama işinde çalışmış ve 5 yıldır uçak akaryakıt ikmal işinde çalışan erkek hasta mesleki periyodik muayenesi için polikliniğimize

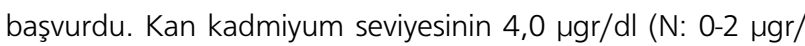
dl) saptanması üzerine hastaneye yatırıldı. Özgeçmişinde, sistemik hastalığı ve sigara kullanımı yoktu. Akut/subakut kadmiyum intoksikasyon etkileri (mukozal irritasyon, öksürük, dispne, göğüs ağrısı) saptanmadı. Fizik muayenesi normaldi. Mesleki akciğer hastalığı açısından göğüs hastalıkları ile konsülte edildi. Posterior-anterior akciğer grafisi ve solunum fonksiyon testi normaldi. Kemik mineral dansitometrisinde (KMD) femur boyun T skoru -3,78, lomber 2-4 vertebra T skoru -2,6; femur boyun z skoru $-2,85$ ve lomber $2-4$ vertebra z skoru -2,51 olarak saptandı. Osteoporoz açısından risk faktörleri sorgulandığında; düşük vücut kitle indeksi, aşırı alkol tüketimi, sedanter yaşam, sigara, ailede kırık öyküsü, kötü beslenme ve geçirilmiş gastrointestinal sistem operasyonu öyküsü yoktu. 25-OH vitamin D düzeyi 22,48 $\mu \mathrm{gr}$ /L (N: 10-80 $\mu \mathrm{gr} / \mathrm{L})$ ve osteokalsin düzeyi 18,93 ng/mL idi (N: 3,1-13,7) idi. Osteoporozun sekonder nedenlerini ekarte etmek için istenen tam kan sayımı, eritrosit sedimentasyon hızı, karaciğer ve böbrek fonksiyon testleri, total protein ve albumin düzeyi, vitamin B12, demir düzeyi, tiroid (TSH, ST3, ST4) ve paratiroid hormon düzeyleri, prolaktin, lüteinizan hormon, testosteron, immunglobulin E, Beta-2 mikroglobulin, kalsiyum, fosfor ve alkalen fosfataz seviyeleri normaldi. Sekonder osteoporozun diğer nedenleri saptanamayan olgumuza olası kadmiyum maruziyetine bağlı osteoporoz tanısı kondu. Erkek osteoporozunda onay almış (5) zoledronik

Yazışma Adresi/Address for Correspondence: Dr. Timur Ekiz, Ankara Fizik Tedavi ve Rehabilitasyon Eğitim ve Araştırma Hastanesi, Fizik Tedavi ve Rehabilitasyon Kliniği, Ankara, Türkiye GSM: +90 5353055752 E-posta: timurekiz@gmail.com Geliş Tarihi/Received: 27.09.2013 Kabul Tarihi/Accepted: 03.01.2014

Türk Osteoporoz Dergisi, Galenos Yayınevi tarafindan basılmıştır. / Turkish Journal of Osteoporosis, published by Galenos Publishing. 
asit 5 mg/yıl ve kalsiyum-D vitamini 1200 mg-800 IU/gün başlandı. Osteoporoz diyeti ve egzersizleri önerilerek 6 ay sonrası için KMD kontrolü planlandı.

\section{Tartışma}

Kadmiyum doğada doğal olarak bulunan bir metaldir. Ancak endüstriyel ve tarımsal kontaminasyon nedeniyle kronik kadmiyum maruziyeti özellikle gelişmekte olan ülkelerde önemli bir sorundur (3). Kadmiyum maruziyeti için riskli meslek grupları Tablo 1'de verilmiştir $(2,6)$.

Kadmiyumun osteoporoz üzerine etkileri daha önce bildirilmiş olmasına rağmen altta yatan mekanizma kesinleşmemiştir. Normal kemik metabolizması, osteoblastik ve osteoklastik aktivitelerin denge içerisinde devam ettiği aktif bir süreçtir. Bu kemik döngüsünün fizyopatolojisinde oksidatif ve antioksidatif durum oldukça önemlidir ve oluşan reaktif oksijen türevleri bu döngüyü rezorptif süreç, yani osteoklastik aktivite lehine çevirmektedir (7). Ognjanovic ve ark. (8) kadmiyumun hidroksil $(\mathrm{OH})$, süperoksit anyonu (O2-) ve hidrojen peroksit $(\mathrm{H} 2 \mathrm{O} 2)$ gibi serbest oksijen radikallerini indüklediğini belirtmişlerdir. Bunun yanında, kadmiyumun kemikte direk etki ile osteoklastları etkileyerek matriks dokusunun yıkımına neden olduğu da belirtilmiştir. Kadmiyum, indirekt olarak da böbrek üzerindeki etkileri (hiperkalsiüri) ile kemik mineralizasyonuna etki eder $(1,2)$. Youness ve ark. (7) $25-\mathrm{OH}$ vitamin D'nin aktif formu olan 1.25-OH vitamin D'ye dönüşümünü inhibe ederek kemik metabolizmasına etki ettiğini bildirmiştir. Ayrıca kronik kadmiyum maruziyeti serum kalsiyum, fosfor ve parathormon düzeylerinde artış ile vitamin $D$, alkalen fosfataz ve osteokalsin düzeylerinde azalma ile ilişkili bulunmuştur. Yine, kadmiyumun osteoblast gen ekspresyonunu değiştirdiği ve bu şekilde osteoporoza neden olduğu bildirilmiştir (9). Bunun yanında, İtai-Itai Hastalığı kronik kadmiyum maruziyetinin en ağır formudur ve genellikle postmenapozal kadınlarda görülür. Osteoporoz, osteomalazi, renal tübüler disfonksiyon ve renal anemi ile karakterizedir (10). Bizim vakamızda kadmiyuma bağlı sadece KMD'de düşüklük saptanmıştır. Olgumuzun akaryakıt ikmalinde ve metal kaplama işinde çalışmış olması kadmiyum ve diğer metallere maruziyeti için risk faktörü oluşturmaktadır. Ancak, her ne kadar sadece kadmiyum seviyesi kanda yüksek çıkmış olsa da diğer metallerin

\section{Tablo 1. Kadmiyum maruziyeti için riskli meslek}

\section{grupları}

- Lehimleme

- Kaynakçlık

- Plastik boya

- Seramik endüstrisi

- Uçak ve cam endüstrisi

- Cila üretimi ve işlenmesi

- Akümülatör sanayi

- Kadmiyum içeren eritme ve metal kaplama

- Bakır eritme

- Batarya üretimi

- Mücevher yapımı maruziyetini ekarte edemeyiz. Çünkü kan metal seviyeleri son zamanlardaki maruziyeti göstermektedir. Daha uzun süreli maruziyeti göstermek için diğer doku örnekleri (saç, tırnak) incelenmelidir. Ayrıca kemikte metal birikimini göstermek için x-ray floresans spektroskopisi yöntemi ile inceleme gerekmektedir (11). Ancak ülkemizde maalesef bu tetkik bulunmamaktadır. Ek olarak, olgumuzda kırık şüphelendirilecek vertebra ya da kalça ağıısı olmaması, fizik muayenesinde kifotik görünümün olmaması ve dejeneratif değişikliklerin beklendiği yaş grubunda olmaması nedeniyle direkt grafi ile görüntüleme yapılmamıştır. Kadmiyuma bağlı gelişen osteoporozun tedavisinde ise literatürde standart bir tedavi kılavuzu olmamakla birlikte bizim vakamıza erkek osteoporozunda ilk seçenek olarak önerilen bifosfonat tedavisi düşünülmüş ve kullanım kolaylığı (yılda bir kez), tedaviye uyumun yüksek olması ve böbrek fonksiyon testlerinin normal olması nedeniyle zoledronik asit tedavisi tercih edilmiştir.

\section{Sonuç}

Osteoporoz ve komplikasyonları önemli morbidite ve mortalite nedeni olduğundan kadmiyum maruziyetinin iş yerlerinde önlenmesi gerektiğini ve ilgili meslek dallarında çalışan kişilerde olası osteoporozun araştıııması ve tedavisinin düzenlenmesinin önemini vurgulamaktayız. Meslek hastalıklarının önlenmesi, erken tanısı ve tedavisi özürlülüğün ve iş gücü kaybının önlenmesi, birey ve toplum sağlığı için önemlidir.

\section{Kaynaklar}

1. James KA, Meliker JR. Environmental cadmium exposure and osteoporosis: a review. Int J Public Health 2013;58:737-45.

2. Chakraborty S, Dutta AR, Sural S, Gupta D, Sen S. Ailing bones and failing kidneys: a case of chronic cadmium toxicity. Ann Clin Biochem 2013;50:492-5.

3. Wallin M, Sallsten G, Fabricius-Lagging E, Öhrn C, Lundh T, Barregard L. Kidney cadmium levels and associations with urinary calcium and bone mineral density: a cross-sectional study in Sweden. Environ Health 2013;12:22.

4. Yang $H$, Huo X, Yekeen TA, Zheng Q, Zheng M, Xu X. Effects of lead and cadmium exposure from electronic waste on child physical growth. Environ Sci Pollut Res Int 2013;20:4441-7.

5. Ruza I, Mirfakhraee S, Orwoll E, Gruntmanis U. Clinical experience with intravenous zoledronic acid in the treatment of male osteoporosis: evidence and opinions. Ther Adv Musculoskelet Dis 2013;5:182-98.

6. Çalışma ve Sosyal Güvenlik Bakanlığı, İs Sağlığı ve Güvenliği Genel Müdürlüğü. In: Meslek hastalıkları Rehberi. Matsa Basımevi, 2011, Ankara p. 105-11.

7. Youness ER, Mohammed NA, Morsy FA. Cadmium impact and osteoporosis: mechanism of action. Toxicol Mech Methods 2012;22:560-7.

8. Ognjanovic BI, Markovic SD, Ethordevic NZ, Trbojevic IS, Stajn AS, Saicic ZS. Cadmium-induced lipid peroxidation and changes in antioxidant defense system in the rat testes: protective role of coenzyme Q(10) and vitamin E. Reprod Toxicol 2010;29:191-7.

9. Uchida $H$, Kurata $Y$, Hiratsuka $H$, Umemura $T$. The effects of a vitamin D-deficient diet on chronic cadmium exposure in rats. Toxicol Pathol 2010;38:730-7.

10. James KA, Meliker JR. Environmental cadmium exposure and osteoporosis: a review. Int J Public Health. 2013;58:737-45.

11. Flora G, Gupta D, Tiwari A. Toxicity of lead: A review with recent updates. Interdiscip Toxicol 2012;5:47-58. 